\title{
Impact of Facilities and Service Quality on Patient Relatives Satisfaction and Patronage in University of Maiduguri Teaching Hospital, Borno State, Nigeria
}

\author{
Abubakar Mammadi ${ }^{1}$, Hussaini Alhassan Funtua ${ }^{2}$, Usman Alhaji Muktar ${ }^{2}$, Bala Jibrin ${ }^{3}$
}

${ }^{1}$ Abubakar Tafawa Balewa University

Tafawa Balewa Way, P. M. B. 0248, Bauchi, 740272, Nigeria

2 The Federal Polytechnic Damaturu

P. M. B. 1006 Damaturu, Yobe State, Nigeria

${ }^{3}$ Bilyaminu Othman College of Education Das

39 Sabon Gari Street, Dass, Bauchi, Nigeria

DOI: $10.22178 /$ pos.68-2

JEL Classification: L84

Received 13.02.2021

Accepted 25.03.2021

Published online 31.03.2021

Corresponding Author:

Abubakar Mammadi

abubakarmammadi@gmail.com

(C) 2021 The Authors. This article is licensed under a Creative

Commons Attribution 4.0 License

(c) (1)

\begin{abstract}
The study aimed at evaluating the impact of facilities and service quality in the University of Maiduguri Teaching Hospital. The study assesses the level of service quality and facilities provided to the patient's relative satisfaction and patronage. The study adopted a quantitative approach, and data were collected through a questionnaire survey from 225 patients relative to the UMTH proportionately selected from the target population in the Borno metropolis. The data collected were subjected to descriptive and inferential statistics with mean ranking, frequency distribution and Partial Least Square - Structural Equation Model (PLS-SEM) to achieve the research aim. The study indicated that service quality has the most potent effect on patronage, followed by satisfaction with a significant effect and facilities provided with a small size effect. The study also indicated hypothesised path relationship between service quality and patronage is statistically significant. The study reported that hypothesised path relationship between satisfaction and patronage is statistically significant. The study demonstrated that hypothesised path relationship between facilities provision and patronage is not statistically significant. It can be depicted that service quality and satisfaction are both moderately strong predictors of patronage, but facilities provision does not predict patronage directly. The study finally recommended that management intervenes through the provision of maintenance culture, enhancing the quality of services and facilities for satisfaction and patronage.
\end{abstract}

Keywords: patronage; service quality; facilities provision; hospital and satisfaction.

\section{INTRODUCTION}

The service sector is a rapidly growing area of the world economy, and health service organisations play a pivotal role in such development. Service quality is essential, especially in customer's retention. Customers have become quality conscious and expect all services to be of high quality. Competition plays a vital role in upgrading quality and patient's satisfaction in health care institutions. In environments where there is no competition significantly when demand exceeds supply, hospitals officer their patient's unsatisfactory service due to the idea that patients have no other alternative and they would comply with the present service unconditionally. Hospitals provide differentiation based on the quality of service. To have a consistent competitive advantage, service sectors like hospitals argue against providing excellent services to their customer.

To win today's market place entails building customer relationship and not just building the products; building customer relationship means delivering superior value over competitors to the target customers. Evaluating the company's service quality is mainly based on the customers; it 
is evident that customers play essential roles in the organisational process. Whether an organisation provides good service quality or not will depend on the customers' feedback on the satisfaction they get from consuming the products since higher quality levels lead to higher customer satisfaction levels.

The organisation that focuses on customer satisfaction can build loyal clients who promote the organisation further through vital word of mouth advertising referrals. The private health care sector (including unqualified providers) also deserves scrutiny as $70 \%$ of the patients seek medical care from this sector [15]. A study suggested that the overall utilisation rate for public health care service is as low as $30 \%$. Studies also maintain that public hospitals' service quality is better than private hospitals. Another study reveals that private hospitals' quality is better than in public health facilities. Furthermore, a lot of grievances regarding health care delivery have been directed towards government hospitals.

\section{Literature review}

Facilities are primarily physical, social, and institutional forms of capital, enhancing production, distribution, consumption activities, and ultimately, life quality. It constitutes essential services without which primary, secondary and tertiary productive activities cannot function. Facilities form the necessary ingredients for motivating people to be more productive and achieve relative self-reliance. In other words, facilities are elements in the package of basic needs which a community would like to procure for better living. It is viewed as those facilities and services that are needful to improve people's quality of life. Some authors put facilities to include the system of physical, human, and institutional forms of capital, enabling rural residents to perform their production, processing better, and distribution activities and improving the overall quality of life. Also, facilities can be better understood as specialised elements in the development process that bring about improvements in the masses' socio-economic welfare. Moreover, they are catalysts of development, and at the same time, their presence can be an indicator of the development level.

Some authors had assisted in categorising the facilities to include - economic such as credit, loan, production support; physical infrastruc- tures such as roads, electricity, irrigation facilities; capacity building in terms of training, information dissemination; and support service namely, market services, and access to essential social services. Some researchers had attempted the classification of the facilities into three, namely, first: physical facilities consisting of roads, bridges, storage facilities, dams, irrigation, water facilities, and other forms of processing facilities. Second, social facilities such as health and medical facilities, educational facilities and third, institutional facilities consist of cooperative societies, farmers' unions, financial institutions like banks, agricultural extension and training services. This classification is of immense importance because people's socio-economic status largely depends on the quality of infrastructural facilities provided with good maintenance culture.

Moreover, the author [3] shared a similar opinion that the provision of basic facilities is a prerequisite for developing economies to stimulate economic growth and reach the state of economic recovery and poverty alleviation through increasing and diversifying agricultural outputs.

Also, authors $[15,24]$ observed that facilities are part of an integrated development strategy that combines various society areas, including agricultural, educational, health, nutrition, electrification, water supply and cooperatives simultaneously. The same vein had remarked that adequate facilities provision could reduce the production cost, affecting productivity, output, and employment.

Service quality has also been defined as customer perception of how well a service meets or exceeds its expectations. In defining service quality, some authors argue that it is a consumer's overall mental picture of the relative inferiority or superiority of the organisation and its services. Therefore, the service quality is interpreted as the impression of a customer's judgment concerning the service provided. Service quality is influenced by expected service and perceived service. If services are received as expected, the service quality is satisfactory. Still, if the services exceeded their expectations, customers will be delighted and perceive service quality as excellent and vice versa. Some authors refer to service quality focuses specifically on dimensions of service.

Some studies on service quality have been carried out in the health sector; however, no single definition can adequately delineate what health 
is all about. The World Health Organization Constitution defines health as a complete physical, mental, social well-being and not merely the absence of disease or infirmity [36]. Also defined health care quality as the kind of care that is anticipated to maximise an inclusive measure of patient welfare after taking account of the process of care in all its parts [22]. Some authors define health care quality by underscoring the importance of life, stating that which consistently contributes to the betterment or maintenance of the quality or duration of life. They further highlight the relevance of disease prevention, health promotion, informed participation of patients and efficient use of resources as critical variables in healthcare quality. Highlights desired outcome consistent with professional knowledge. According to [31], it is the degree to which health services for individuals and populations increase the likelihood of desired health outcomes and are consistent with current professional knowledge.

Some authors define quality considered the needs of patients and the financial resources of a facility; and argued that it is fully meeting the needs of those who need the service most, at the lowest cost to the organisation within bounds and directive of higher authorities and purchasers. According to [31], even though there are several definitions of healthcare service quality in literature, it is still a complicated and indistinct concept. Fuentes [4] concurs to [31] opinion by stating that the quality of healthcare service is a multidimensional concept that reflects a judgment about whether the services provided for patients were appropriate and whether the relationship between doctors and patients was proper. One of the traditional medical approaches to the definition of quality of healthcare focuses on healthcare services' outcome from the service provider's point of view. In contrast, another approach emphasises healthcare from the patient's perspective. In general, researchers define the quality of healthcare services along two dimensions; technical service and interpersonal care of service.

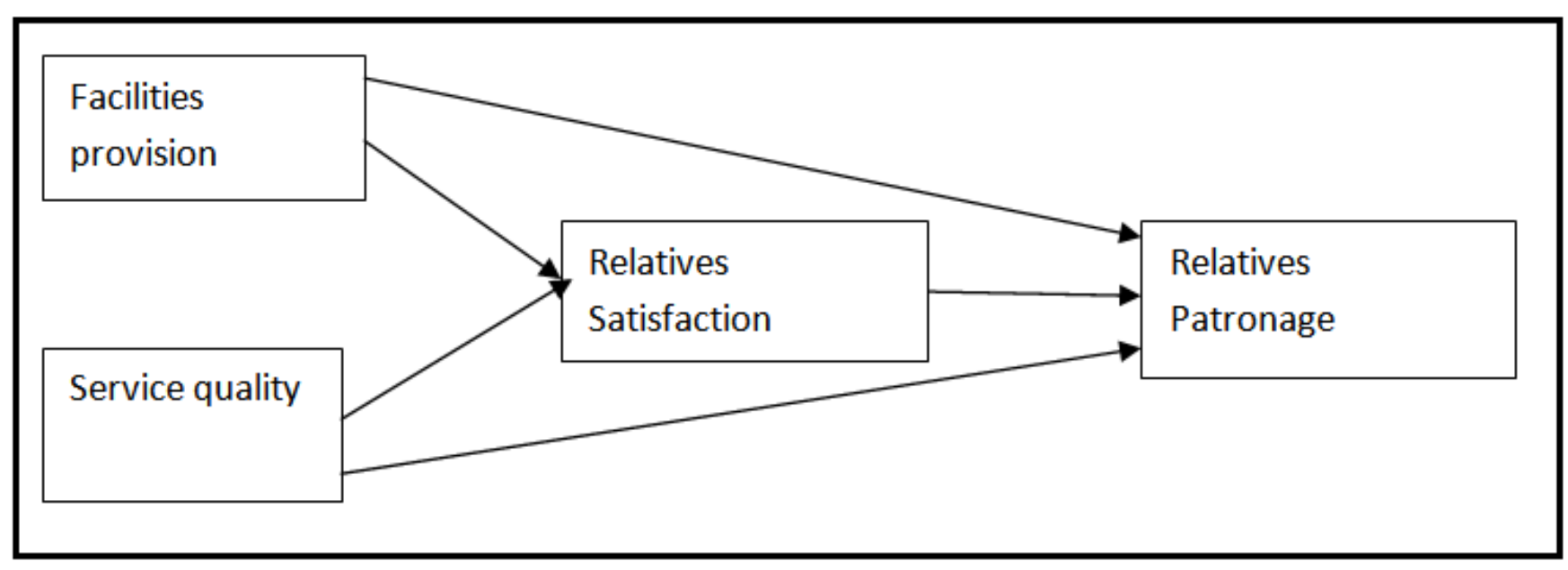

Figure 1 - Study conceptual framework

\section{MATERIALS AND METHOD}

The study population is the target respondents to the study that fulfil the requirement to supply information needed for the research. This study's target population are patient relatives in University Maiduguri Teaching Hospital (UMTH) who are staying with the patients.

The sample frame is the total number of target respondents. The sampling frame refers to a complete list of all units in the population under study and determines the inquiry structure. Some authors define a sample as "a proportion of a population". This study's sample frame is the total number of two patient relatives per 533bed capacity, which are 1066 .

The sample size is an essential feature of any empirical study in which the goal is to make inferences about a population from a sample. In practice, the sample size used in a study is determined based on the expense of data collection and the need to have sufficient statistical power. The sample size is 306 based on a sample frame of 1066 patient relatives. The sample size for this study was determined using Bartlett's table.

As the University Maiduguri Teaching Hospital comprises six (6) wards with a total bed capacity of 533, and since the hospital management al- 
lowed only two (2) patients relative to stay with the patients (as presented in Table 1), the sample size will be proportionally assigned.

Table 1 - Demographics of the respondents

\begin{tabular}{|c|c|c|c|c|}
\hline No & Attributes & Options & Frequency & Percentage \\
\hline \multirow[t]{3}{*}{1} & \multirow[t]{3}{*}{ Gender } & Male & 110 & 48.9 \\
\hline & & Female & 115 & 51.1 \\
\hline & & & 225 & 100 \\
\hline 2 & \multirow[t]{4}{*}{ Age } & $\begin{array}{l}\text { Under } 30 \\
\text { years }\end{array}$ & 99 & 44.0 \\
\hline & & $\begin{array}{l}30 \text { to } 60 \\
\text { years }\end{array}$ & 94 & 41.8 \\
\hline & & $\begin{array}{l}\text { Above } 60 \\
\text { years }\end{array}$ & 32 & 14.2 \\
\hline & & & 225 & 100 \\
\hline \multirow[t]{4}{*}{3} & \multirow{4}{*}{$\begin{array}{l}\text { How often } \\
\text { do you visit } \\
\text { this hospital }\end{array}$} & $\begin{array}{l}\text { Most of } \\
\text { the time }\end{array}$ & 57 & 25.3 \\
\hline & & \begin{tabular}{|l|} 
Some \\
times
\end{tabular} & 122 & 54.2 \\
\hline & & First time & 46 & 20.4 \\
\hline & & & 225 & 100 \\
\hline \multirow[t]{6}{*}{4} & \multirow[t]{6}{*}{ Occupation } & $\begin{array}{l}\text { Civil serv- } \\
\text { ant }\end{array}$ & 47 & 20.9 \\
\hline & & Business & 50 & 22.2 \\
\hline & & Farmer & 47 & 20.9 \\
\hline & & Student & 60 & 26.7 \\
\hline & & $\begin{array}{l}\text { None of } \\
\text { the above }\end{array}$ & 21 & 9.3 \\
\hline & & & 225 & 100 \\
\hline \multirow[t]{6}{*}{5} & \multirow[t]{5}{*}{\begin{tabular}{|l|} 
Educational \\
Qualification
\end{tabular}} & $\begin{array}{l}\text { Informal/ } \\
\text { Primary } \\
\text { Education }\end{array}$ & 21 & 9.3 \\
\hline & & $\begin{array}{l}\text { Secondary } \\
\text { certificate }\end{array}$ & 86 & 38.2 \\
\hline & & Diploma & 98 & 43.6 \\
\hline & & Degree & 13 & 5.8 \\
\hline & & $\begin{array}{l}\text { Master } \\
\text { degree } \\
\text { and above }\end{array}$ & 7 & 3.1 \\
\hline & & & 225 & 100 \\
\hline
\end{tabular}

The procedure for choosing the sample units from a population is known as sampling. While the study population may be finite or infinite, the sample is finite. There are various techniques for selecting units that make up the sample, categorised into probability and non-probability techniques. In respect of this study, a random sampling technique was used to collect unbiased data from each ward, while a purposeful sample was adopted to administer the questionnaire.

For this research, the questionnaire was adopted to collect data from the respondents in the study area. The design incorporated the use of only close-ended questions. The close-ended question had more than one response options and five (5) Likert scale used for the variables items to ease assessing the responses.

This study used structured questionnaires to generate quantitative data from the respondents. The study employed the use of descriptive statistic (Mean Ranking) and inferential statistic (Partial Least Squares (PLS)) to analyse the data collected. SPSS was used to analyse the data generated from the questionnaire survey.

Table 2 - Sample Frame and Sample Size

\begin{tabular}{|l|c|c|}
\hline \multicolumn{1}{|c|}{ Ward/Dept. } & $\begin{array}{l}\text { Number of Bed } \\
\text { (sample frame) }\end{array}$ & $\begin{array}{c}\text { No. of Patients } \\
\text { Relative (sample } \\
\text { size) }\end{array}$ \\
\hline $\begin{array}{l}\text { Obstetrics and } \\
\text { Gynaecology }\end{array}$ & 136 & 57 \\
\hline Medicine & 141 & 60 \\
\hline Surgery & 145 & 61 \\
\hline $\begin{array}{l}\text { Paediatric Medi- } \\
\text { cal }\end{array}$ & 88 & 37 \\
\hline Amenity & 19 & 8 \\
\hline $\begin{array}{l}\text { Intensive Care } \\
\text { Unit }\end{array}$ & 4 & 2 \\
\hline TOTAL & 533 & 225 \\
\hline
\end{tabular}

There are many kinds of validity, but they all refer to whether the data being measured truly reflects what it ought to be. Reliability refers to consistency and the ability to obtain the same answer each time a measure is used. There are three types of reliability test: inter-ratter, internal consistency, and test-retest. The validity test determines if a measurement truly reflects the concept being studied. There are three common types of validity: internal, external, and construct. Reliability test determines the consistency that researchers should obtain the same answer each time a measure is used. It is concerned with how consistent the result obtained with the instruments is. The instrument gives similar, close or the same result if the study is replicated under the same assumptions and conditions. The reliability of the constructs was analysed by finding Cronbach's alpha, as Pallant suggested. Overall, Cronbach's alpha for the questionnaire was 0.853 . This means that the questionnaire as a whole is reliable and acceptable. 
Table 3 - Reliability results

\begin{tabular}{|l|l|l|}
\hline Constructs & Cronbach's Alpha & N of Items \\
\hline Service quality & .848 & 13 \\
\hline Facilities provision & .853 & 13 \\
\hline Satisfaction & .842 & 13 \\
\hline Patronage & .674 & 5 \\
\hline
\end{tabular}

The results presented in the table above indicated that the Cronbach's alphas obtained for each of the constructs, facilities provision having the highest score of 0.853 and the patronage having the lowest value of .674 . However, all the results were above the acceptable range of 0.7 except for patronage.

\section{RESULTS AND DISCUSSION}

What is the level of service quality in University Maiduguri Teaching Hospital? Descriptive statistical analysis was used to explore service quality in the University of Maiduguri Teaching Hospital Borno State.

Table 4 shows the level of service quality in the University of Maiduguri Teaching Hospital.

Table 4 - Level of service quality

\begin{tabular}{|l|l|l|l|l|}
\hline No & \multicolumn{1}{|c|}{ Variables } & Mean & \multicolumn{1}{|c|}{$\begin{array}{c}\text { St. } \\
\text { deviation }\end{array}$} & Ranking \\
\hline 1 & Internet connectivity & 3.22 & 1.154 & 1st \\
\hline 2 & Hygiene services & 2.90 & 1.111 & 2nd \\
\hline 3 & $\begin{array}{l}\text { Recreational } \\
\text { services }\end{array}$ & 2.88 & 1.126 & 3rd \\
\hline 4 & Laundry services & 2.86 & 1.125 & 4th \\
\hline 5 & Security service & 2.85 & 1.091 & 5th \\
\hline 6 & Electricity supply & 2.79 & 1.118 & 6th \\
\hline 7 & Sales services & 2.77 & 1.003 & 7th \\
\hline 8 & Response service & 2.72 & 1.041 & 8th \\
\hline 9 & Transportation & 2.63 & .992 & 9th \\
\hline 10 & Cleaning services & 2.55 & 1.070 & 10th \\
\hline 11 & $\begin{array}{l}\text { Communication } \\
\text { services }\end{array}$ & 2.55 & 1.073 & 11th \\
\hline 12 & Safety services & 2.44 & .972 & 12th \\
\hline 13 & Water supply & 2.22 & 1.057 & 13th \\
\hline
\end{tabular}

It shows that the service quality provided most, based on a five-point measurement scale, was Internet connectivity, with a mean score of 3.22 ranked 1st. In contrast, electricity with the mean value of 2.79 ranked $6^{\text {th }}$.

What is the level of facilities provided in the University of Maiduguri Teaching Hospital? A descriptive statistical analysis was used to identify the level of facilities provided in the Teaching Hospital.

Table 5 shows the level of facilities provided in the University of Maiduguri Teaching Hospital. It shows that the facilities provided most, based on the five-point measurement scale, were security services with a mean score of 3.05 ranked 1st.

Table 5 - Level of facilities provision

\begin{tabular}{|l|l|c|c|c|}
\hline No & \multicolumn{1}{|c|}{ Variables } & Mean & St. deviation & Ranking \\
\hline 1 & Security service & 3.05 & 1.205 & 1 st \\
\hline 2 & $\begin{array}{l}\text { Recreational } \\
\text { services }\end{array}$ & 2.88 & 1.126 & 2nd \\
\hline 3 & $\begin{array}{l}\text { Electricity } \\
\text { supply }\end{array}$ & 2.83 & 1.068 & 3 rd \\
\hline 4 & $\begin{array}{l}\text { Response } \\
\text { service }\end{array}$ & 2.82 & 1.068 & 4 th \\
\hline 5 & $\begin{array}{l}\text { Communication } \\
\text { services }\end{array}$ & 2.81 & 1.045 & 5 th \\
\hline 6 & $\begin{array}{l}\text { Internet } \\
\text { connectivity }\end{array}$ & 2.75 & 1.131 & 6 th \\
\hline 7 & Hygiene services & 2.72 & 1.069 & 7 th \\
\hline 8 & $\begin{array}{l}\text { Cleaning } \\
\text { services }\end{array}$ & 2.71 & 1.122 & 8th \\
\hline 9 & Transportation & 2.68 & .974 & 9th \\
\hline 10 & Sales services & 2.64 & 1.082 & 10th \\
\hline 11 & $\begin{array}{l}\text { Laundry } \\
\text { services }\end{array}$ & 2.58 & 1.103 & 11 th \\
\hline 12 & Safety services & 2.58 & .984 & 12th \\
\hline 13 & Water supply & 2.26 & 1.075 & 13th \\
\hline
\end{tabular}

What is the level of patient relative satisfaction with facility provision and service quality in the study area? A descriptive statistical analysis was used to identify the level of satisfaction with the facility's facility in the University of Maiduguri Teaching Hospital.

Table 6 shows satisfaction with facility provision and service quality in the University of Maiduguri Teaching Hospital. It shows that the satisfaction with facility provision and service quality provided most, based on the five-point measurement scale, was security service with a mean score of 3.14 ranked $1^{\text {st. }}$.

Table 6 - Level of facilities provision

\begin{tabular}{|l|l|l|l|l|}
\hline No & \multicolumn{1}{|c|}{ Variables } & Mean & $\begin{array}{c}\text { St. } \\
\text { deviation }\end{array}$ & Ranking \\
\hline 1 & Security service & 3.14 & 1.159 & 1st \\
\hline 2 & $\begin{array}{l}\text { Recreational } \\
\text { services }\end{array}$ & 2.96 & 1.070 & 2nd \\
\hline 3 & Internet connectivity & 2.86 & 1.137 & 3rd \\
\hline
\end{tabular}




\begin{tabular}{|l|l|l|l|l|}
\hline No & \multicolumn{1}{|c|}{ Variables } & Mean & $\begin{array}{c}\text { St. } \\
\text { deviation }\end{array}$ & Ranking \\
\hline 4 & Response service & 2.86 & 1.055 & 4th \\
\hline 5 & Electricity supply & 2.80 & 1.099 & 5th \\
\hline 6 & $\begin{array}{l}\text { Communication } \\
\text { services }\end{array}$ & 2.72 & 1.090 & 6th \\
\hline 7 & Laundry services & 2.71 & 1.181 & 7th \\
\hline 8 & Transportation & 2.68 & 1.021 & 8th \\
\hline 9 & Hygiene services & 2.67 & 1.100 & 9th \\
\hline 10 & Cleaning services & 2.66 & 1.086 & 10th \\
\hline 11 & Safety services & 2.53 & .987 & 11th \\
\hline 12 & Sales services & 2.52 & .973 & 12th \\
\hline 13 & Water supply & 2.23 & 1.029 & 13th \\
\hline
\end{tabular}

\begin{tabular}{|l|l|l|l|c|}
\hline & $\begin{array}{l}\text { relatives and } \\
\text { friends to visit } \\
\text { the hospital }\end{array}$ & & \\
\hline 5 & $\begin{array}{l}\text { Willingness to } \\
\text { stay long } \\
\text { inside the } \\
\text { wards }\end{array}$ & 2.40 & 1.146 & 5 th \\
\hline
\end{tabular}

To what extent are patient relative willing to patronise the study area? A descriptive statistical analysis was used to identify the extent are patient relative willing to patronise.

Table 7 shows the level of patient relative patronage in the University of Maiduguri Teaching Hospital. It reported that willing to be visiting the hospital with a mean score of 2.91 ranked $1^{\text {st. }}$

Table 7 - Patient relative willing to patronise

\begin{tabular}{|l|l|c|c|c|}
\hline No & \multicolumn{1}{|c|}{ Variables } & Mean & St. Deviation & Ranking \\
\hline 1 & $\begin{array}{l}\text { Willing to be } \\
\text { visiting the } \\
\text { hospital }\end{array}$ & 2.91 & 1.138 & 1 st \\
\hline 2 & $\begin{array}{l}\text { Willing to } \\
\text { recommend } \\
\text { the hospital } \\
\text { for people to } \\
\text { come }\end{array}$ & 2.76 & 1.078 & 2nd \\
\hline 3 & $\begin{array}{l}\text { Willingness to } \\
\text { stay long } \\
\text { outside the } \\
\text { wards }\end{array}$ & 2.76 & 1.085 & 3 rd \\
\hline 4 & $\begin{array}{l}\text { Willing to } \\
\text { invite your }\end{array}$ & 2.68 & .997 & 4 th \\
\hline
\end{tabular}

What are Facilities Provision and service quality on patient's relative satisfaction and patronage in the study area? To determine the effect of facilities provisions and service quality on patient's relative's satisfaction and patronage in the study area, the Partial Least Squares-Structural Equation Modelling (PLS-SEM) was used.

Some authors suggested that some essential elements should be covered for an initial assessment of the PLS-SEM model.

These include an explanation of target endogenous variable variance, Inner model path coefficient sizes and significance, Outer model loadings and significance, Indicator reliability, Internal consistency reliability, Convergent validity, Discriminant validity and Checking the Structural Path Significance in Bootstrapping, which was presented below.

The convergent validity of the outer (measurement) models was assessed using the factor loadings, Average Variance Extracted (AVE) and composite reliability. Convergent validity was achieved whenever the factor loadings are high and statistically significant. The average variance extracted (AVE) is recommended to be above 0.5 , while composite reliability is recommended to be above 0.6 [33]. The use of Average Variance Extracted (AVE) to measure the convergent validity ensures that each measurement model measures what is supposed to measure.

Table 8 - Average Variance Extracted (AVE)

\begin{tabular}{|l|c|c|c|c|c|}
\hline Variables & Indicators & Factor Loadings & Cronbach's Alpha & Composite Reliability & AVE \\
\hline Facilities provision & F1 & 0.763 & 0.814 & 0.866 & 0.519 \\
\hline & F2 & 0.800 & & & \\
\hline & F4 & 0.736 & & & \\
\hline & F8 & 0.626 & & & \\
\hline & F9 & 0.664 & & & \\
\hline Service Quality & F13 & 0.763 & & & 0.877 \\
\hline & SQ1 & 0.725 & 0.837 & & \\
\hline & SQ2 & 0.771 & & & \\
\hline & SQ3 & 0.693 & & & \\
\hline & SQ4 & 0.767 & & & \\
\hline
\end{tabular}




\begin{tabular}{|l|c|c|c|c|c|}
\hline Variables & Indicators & Factor Loadings & Cronbach's Alpha & Composite Reliability & AVE \\
\hline & SQ7 & 0.638 & & & \\
\hline & SQ8 & 0.643 & & & \\
\hline Satisfaction & SFPH1 & 0.809 & 0.774 & & 0.526 \\
\hline & SFPH2 & 0.751 & & & \\
\hline & SFPH3 & 0.698 & & & \\
\hline & SFPH4 & 0.705 & & & \\
\hline Patronage & SFPH5 & 0.652 & & & 0.580 \\
\hline & WPH1 & 0.813 & 0.637 & & \\
\hline & WPH2 & 0.752 & & & \\
\hline
\end{tabular}

It can be seen that all of the indicators have individual indicator values that are much larger than the minimum acceptable level of 0.6 and close to the preferred level of 0.7. Cronbach's alpha is used to measure internal consistency reliability, but it tends to provide a conservative PLS-SEM measurement. Prior literature has suggested using "Composite Reliability" as a replacement [33]. Such values are shown to be larger than 0.6 , so high internal consistency reliability levels have been demonstrated among all the constructs.

From table 8, it is found that all of the AVE values are greater than the acceptable threshold of 0.5 , so convergent validity and reliability is confirmed.

The discriminant validity was assessed using the constructs' correlation and the constructs' crossloadings. Some authors suggest that AVE's square root in each construct can be used to establish discriminant validity, as indicated in Table 9 below. The cross-loading among the constructs ensured that none of the constructs is loading more in another construct than itself [33].

As seen in table 8 Above, Facilities provision AVE is 0.519 ; hence its square root becomes 0.824 . For service Quality, the AVE is 0.507, and its square roots are 0.761 ; for satisfaction, the AVE is 0.526 , and its square root is 0.725 service quality on the other and has an AVE of 0.580, and its square roots are 0.712 . The result shows that the highest correlation matrix was between Facilities provision and patronage 0.761 . It further shows that none of the research constructs is crossloading more on another construct than itself. It can be concluded that the discriminant validity is well established as the square roots of the AVE are more significant than the correlation values in their respective column and rows. Therefore, the model is suitable for Partial least squares (PLS) regression analysis.
Table 9 - Discriminant Validity

\begin{tabular}{|l|c|c|c|c|}
\hline & $\begin{array}{c}\text { Facilities } \\
\text { provision }\end{array}$ & Patronage & $\begin{array}{c}\text { Satis- } \\
\text { faction }\end{array}$ & $\begin{array}{c}\text { Service } \\
\text { quality }\end{array}$ \\
\hline $\begin{array}{l}\text { Facilities } \\
\text { provision }\end{array}$ & 0.721 & & & \\
\hline Patronage & 0.695 & 0.761 & & \\
\hline Satisfaction & 0.418 & 0.627 & 0.725 & \\
\hline $\begin{array}{l}\text { Service } \\
\text { Quality }\end{array}$ & 0.682 & 0.553 & 0.691 & 0.712 \\
\hline
\end{tabular}

The structural model assessed the effect of facilities provision and service quality on satisfaction and patronage in the study area using the smart PLS 3 interface shown in Figure 2.

The coefficient of determination, $\mathrm{R}^{2}$, is 0.661 for the patronage endogenous latent variable. This means that the three latent variables (Facilities provision, service quality, and satisfaction) moderately explain $66.1 \%$ of the patronage variance. Facilities provision and service quality together explain 0.690 , i.e. $69.0 \%$ of the variance of satisfaction.

The inner model suggests that:

1) Service quality has the most potent effect on patronage (0.471), followed by satisfaction (0.332) and facilities provision (0.060).

2) The hypothesised path relationship between service quality and patronage is statistically significant.

3) The hypothesised path relationship between satisfaction and patronage is statistically significant.

4) However, the hypothesised path relationship between facilities provision and patronage is not statistically significant. This is because its standardised path coefficient (0.060) is lower than 0.1 . 


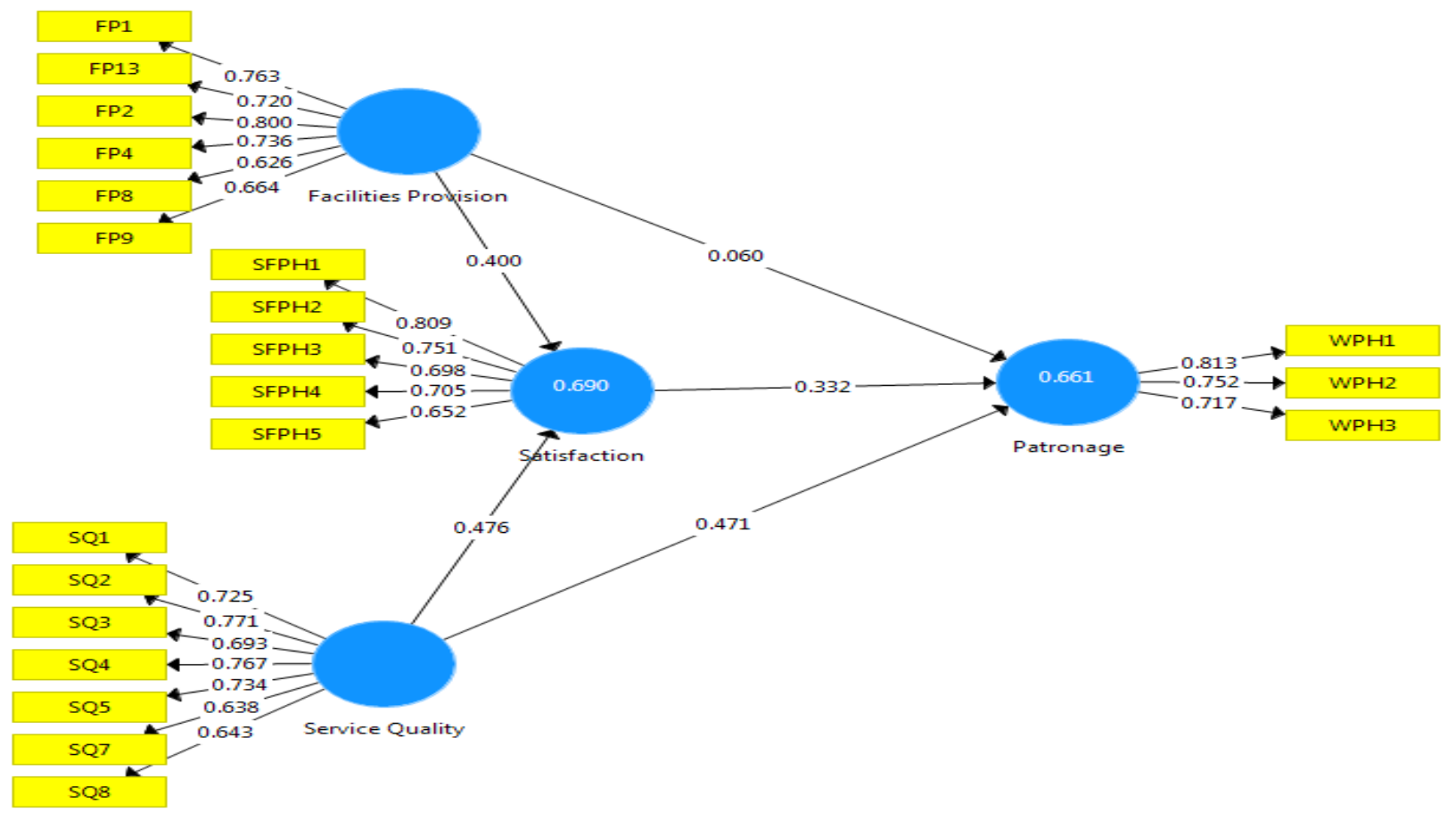

Figure 2 - Effect of Facilities provision and service quality on satisfaction and patronage

Thus, service quality and satisfaction are moderately strong predictors of patronage, but facilities provision does not directly predict patronage.
Figure 3 shows the t-statistics of each construct and indicator.

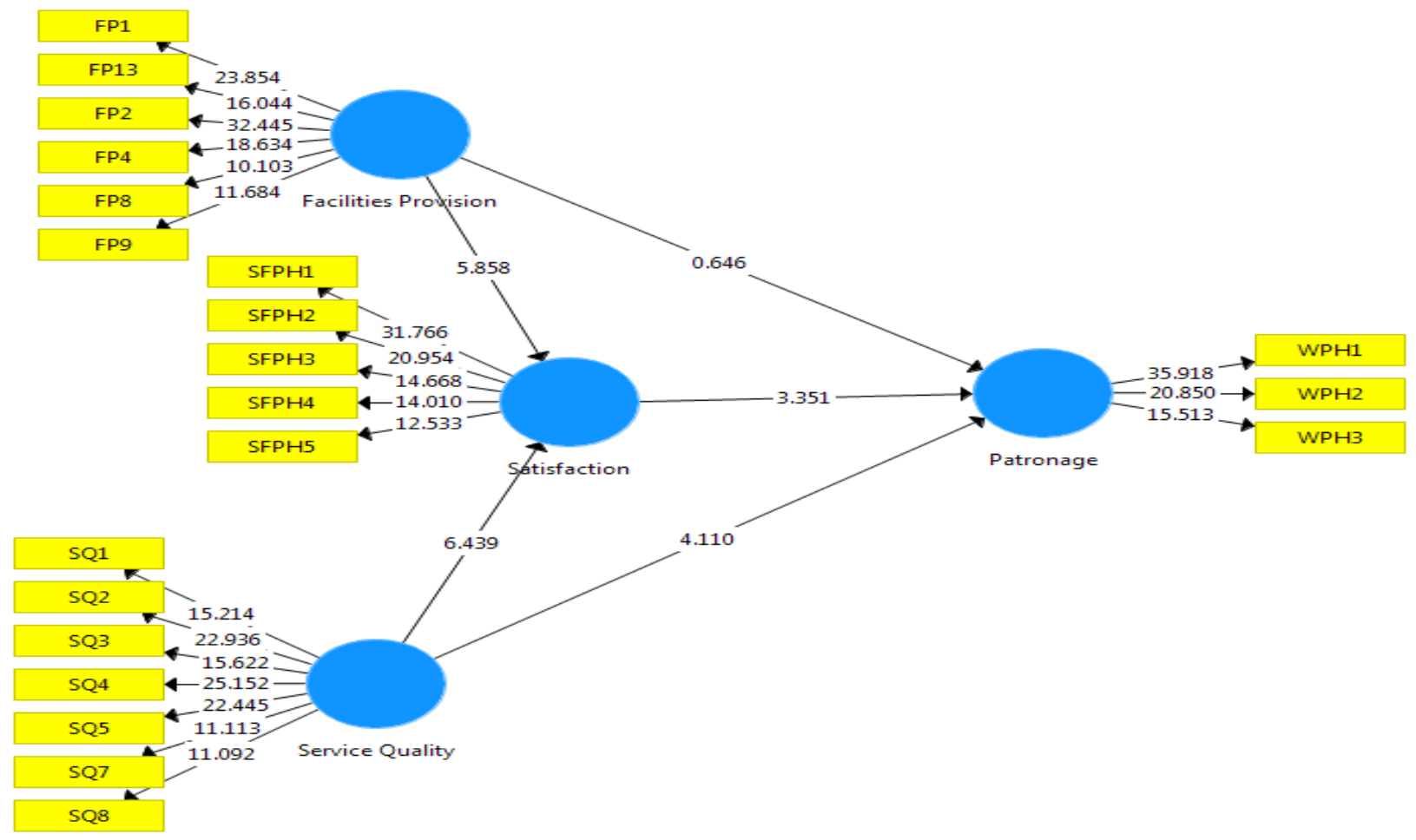

Figure 3 - T-statistics of path coefficients 
The hypothesised relationship's statistical significance was assessed using a two-tailed t-test with a significance level of 5\%. The result shows the effect of Facilities provision and service quality on satisfaction and patronage in the study area.

It can be seen that only "facilities provision - Patronage" linkage with $t$ statistics of 0.646 is not significant because it indicated t-statistics below a minimum threshold of 1.96. However, all other path coefficients, i.e. "satisfaction- patronage linkage" with t-statistics of 3.351, "service quality - patronage" linkage with t-statistics of 4.110, "facilities provision - Satisfaction" linkage with tstatistics of 5.858, "service quality - Satisfaction" Linkage with t-statistics of 6.439 "satisfaction Patronage".

Linkages with t-statistics of 3.351 in the inner model are statistically significant as it indicates tstatistics above the minimum threshold of 1.96 .

Table $10-t$-statistics of path coefficient

\begin{tabular}{|l|c|}
\hline & T-statistics \\
\hline Facilities provision > Patronage & 0.646 \\
\hline Facilities provision > satisfaction & 5.585 \\
\hline Service quality > satisfaction & 6.439 \\
\hline Service Quality > patronage & 4.110 \\
\hline Satisfaction > Patronage & 3.351 \\
\hline
\end{tabular}

The t-statistics of each of the outer loadings in the structural equation modelling is presented in the table below.

Table 11 - t-statistics of outer loadings

\begin{tabular}{|c|c|}
\hline & t-statistics \\
\hline FP1 & 23.854 \\
\hline FP2 & 32.445 \\
\hline FP4 & 18.634 \\
\hline FP8 & 10.103 \\
\hline FP9 & 11.684 \\
\hline FP13 & 16.044 \\
\hline SQ1 & 15.214 \\
\hline SQ2 & 22.936 \\
\hline SQ3 & 15.622 \\
\hline SQ4 & 25.152 \\
\hline SQ5 & 22.445 \\
\hline SQ7 & 11.113 \\
\hline SQ8 & 11.092 \\
\hline
\end{tabular}

\begin{tabular}{|l|l|}
\hline SFPH1 & 31.766 \\
\hline SFPH2 & 20.954 \\
\hline SFPH3 & 14.668 \\
\hline SFPH4 & 14.010 \\
\hline SFPH5 & 12.533 \\
\hline WPH1 & 35.918 \\
\hline WPH2 & 20.850 \\
\hline WPH3 & 15.513 \\
\hline
\end{tabular}

Table 11 shows the t-statistics of the external loadings indicating a value above the minimum threshold of 1.96 .

\section{CONCLUSION}

It can be concluded that the most service quality in the University of Maiduguri Teaching Hospital were hygiene services, recreational services, laundry services and Security service, and the minor service quality was safety services and water supply. The significant facilities provided were security service, recreational services, electricity supply, response service, communication services and internet connectivity. The satisfied facilities provided were security service, recreational services, internet connectivity, response service, electricity supply, and most minor satisfying facilities. The study indicated that patient relatives were willing to visit the hospital, willing to recommend the hospital for people to come, and willing to stay long outside the wards. The study indicated that service quality has the most potent effect on patronage, followed by satisfaction with significant effect and small size effect facilities. The study also indicated hypothesised path relationship between service quality and patronage is statistically significant. The study reported that hypothesised path relationship between satisfaction and patronage is statistically significant. The study demonstrated that hypothesised path relationship between facilities provision and patronage is not statistically significant. It can be concluded that service quality and satisfaction are moderately strong predictors of patronage, but facilities provision does not directly predict patronage.

This study recommended that management intervenes through the provision of maintenance culture, enhancing the quality of services and facilities for satisfaction and patronage. 


\section{REFERENCES}

1. Agyapong, G. K. (2011). The Effect of Service Quality on Customer Satisfaction in the Utility Industry - A Case of Vodafone (Ghana). International Journal of Business and Management, 6(5). doi: 10.5539/ijbm.v6n5p203

2. Aiken, L. H., Sermeus, W., Van den Heede, K., Sloane, D. M., Busse, R., McKee, M., ... Kutney-Lee, A. (2012). Patient safety, satisfaction, and quality of hospital care: cross sectional surveys of nurses and patients in 12 countries in Europe and the United States. BMJ, 344(mar20 2), e1717-e1717. doi: 10.1136/bmj.e1717

3. Ale, M., Abisuwa, T., \& Ologunagba, F. (2011). Rural Infrastructural Developmen, Food Security and City Congestion in Nigeria. Journal of Research in National Development, 9, 124-130.

4. Alrubaiee, L., \& Alkaa'ida, F. (2011). The mediating effect of patient satisfaction in the patients' perceptions of healthcare quality-patient trust relationship. International Journal of Marketing Studies, 3(1), 103-127. doi: 10.5539/ijms.v3n1p103

5. American Psychiatric Association. (2013). Diagnostic and statistical manual of mental disorders (DSM-5 ${ }^{\circledR}$ ). Retrieved from https://www.psychiatry.org/psychiatrists/practice/dsm

6. Anhang Price, R., Elliott, M. N., Zaslavsky, A. M., Hays, R. D., Lehrman, W. G., Rybowski, L., ... Cleary, P. D. (2014). Examining the Role of Patient Experience Surveys in Measuring Health Care Quality. Medical Care Research and Review, 71(5), 522-554. doi: 10.1177/1077558714541480

7. Barr, J., Fraser, G. L., Puntillo, K., Ely, E. W., Gélinas, C., Dasta, J. F., ... Jaeschke, R. (2013). Clinical Practice Guidelines for the Management of Pain, Agitation, and Delirium in Adult Patients in the Intensive Care Unit. Critical Care Medicine, 41(1), 263-306. doi: 10.1097/ccm.0b013e3182783b72

8. Basadur, M., \& Gelade, G. A. (2006). The Role of Knowledge Management in the Innovation Process. Creativity and Innovation Management, 15(1), 45-62. doi: 10.1111/j.1467-8691.2006.00368.x

9. Basch, E. (2014). New Frontiers in Patient-Reported Outcomes: Adverse Event Reporting, Comparative Effectiveness, and Quality Assessment. Annual Review of Medicine, 65(1), 307-317. doi: 10.1146/annurev-med-010713-141500

10. Berry, L. L. (2004). Marketing services: Competing through quality. N. d.: Free Press.

11. Bienstock, C. C., DeMoranville, C. W., \& Smith, R. K. (2003). Organisational citizenship behavior and service quality. Journal of Services Marketing, 17(4), 357-378. doi: 10.1108/08876040310482775

12. Bowen, J. T., \& Chen, S. (2001). The relationship between customer loyalty and customer satisfaction. International Journal of Contemporary Hospitality Management, 13(5), 213-217. doi: 10.1108/09596110110395893

13. Bowling, A. (2014). Research methods in health: investigating health and health services (4th ed.). Maidenhead: Open University Press.

14. Bronzino, J. D. (2014). Management of medical technology: a primer for clinical engineers. Saint Louis: Elsevier Science,

15. Calderon, C. (2009). Infrastructure And Growth In Africa. Policy Research Working Papers. doi: 10.1596/1813-9450-4914

16. Caruana, A. (2002). Service loyalty. European Journal of Marketing, 36(7/8), 811-828. doi: $10.1108 / 03090560210430818$

17. Chi, C. G.-Q., \& Qu, H. (2008). Examining the structural relationships of destination image, tourist satisfaction and destination loyalty: An integrated approach. Tourism Management, 29(4), 624636. doi: 10.1016/j.tourman.2007.06.007

18. Cooper, R. G. (2008). Perspective: The Stage-Gate ${ }^{\circledR}$ idea-to-launch process - Update, What's new, and NexGen systems. Journal of Product Innovation Management, 25(3), 213-232. doi: 10.1111/j.1540-5885.2008.00296.x 
19. D'Mello, M., \& Eriksen, T. H. (2010). Software, sports day and sheera. Information and Organization, 20(2), 81-110. doi: 10.1016/j.infoandorg.2010.03.001

20. Dabholkar, P. A., Shepherd, C. D., \& Thorpe, D. I. (2000). A comprehensive framework for service quality: an investigation of critical conceptual and measurement issues through a longitudinal study. Journal of Retailing, 76(2), 139-173. doi: 10.1016/s0022-4359(00)00029-4

21. Dagger, T. S., Sweeney, J. C., \& Johnson, L. W. (2007). A Hierarchical Model of Health Service Quality. Journal of Service Research, 10(2), 123-142. doi: 10.1177/1094670507309594

22. Donabedian, A. (2003). An introduction to quality assurance in health care. New York: Oxford University Press.

23. Duggirala, M., Rajendran, C., \& Anantharaman, R. N. (2008). Patient-perceived dimensions of total quality service in healthcare. Benchmarking: An International Journal, 15(5), 560-583. doi: 10.1108/14635770810903150

24. Egbetokun, O. A. (2009). Provision of rural infrastructures in Oyo State of Nigeria. Journal of Agricultural Sustainable Practice, 1-2, 69-70.

25. Fan, J.-G., Saibara, T., Chitturi, S., Kim, B. I., Sung, J. J. Y., \& Chutaputti, A. (2007). What are the risk factors and settings for non-alcoholic fatty liver disease in Asia?Pacific? Journal of Gastroenterology and Hepatology, 22(6), 794-800. doi: 10.1111/j.1440-1746.2007.04952.x

26. Gay, G. (2010). Culturally responsive teaching: theory, research, and practice. New York: Teachers College Press.

27. Glaser, B. G., \& Strauss, A. L. (2017). Discovery of grounded theory: Strategies for qualitative research. London : Taylor and Francis.

28. Goleman, D. (2013). Primal leadership: Unleashing the power of emotional intelligence. LaVergne: Harvard Business Press.

29. Gounaris, S., Dimitriadis, S., \& Stathakopoulos, V. (2010). An examination of the effects of service quality and satisfaction on customers' behavioral intentions in e-shopping. Journal of services marketing, 24(2), 142-156. doi: 10.1108/08876041011031118

30. Gremler, D. D., \& Gwinner, K. P. (2000). Customer-Employee Rapport in Service Relationships. Journal of Service Research, 3(1), 82-104. doi: 10.1177/109467050031006

31. Grönroos, C. (2008). Service management and marketing: customer management in service competition. Enskede: TPB.

32. Hagedorn, L. S. (2000). Conceptualising Faculty Job Satisfaction: Components, Theories, and Outcomes. New Directions for Institutional Research, 2000(105), 5-20. doi: 10.1002/ir.10501

33. Hair, J. F. (2016). Essentials of business research methods. New York: Routledge.

34. Han, H., \& Hyun, S. S. (2015). Customer retention in the medical tourism industry: Impact of quality, satisfaction, trust, and price reasonableness. Tourism Management, 46, 20-29. doi: 10.1016/j.tourman.2014.06.003

35. Hu, H.-H. (Sunny), Kandampully, J., \& Juwaheer, T. D. (2009). Relationships and impacts of service quality, perceived value, customer satisfaction, and image: an empirical study. The Service Industries Journal, 29(2), 111-125. doi: 10.1080/02642060802292932

36. Huber, M., Knottnerus, J. A., Green, L., Horst, H. v. d., Jadad, A. R., Kromhout, D., ... Smid, H. (2011). How should we define health? BMJ, 343(jul26 2), d4163-d4163. doi: 10.1136/bmj.d4163

37. Hui, E. C. M., \& Zheng, X. (2010). Measuring customer satisfaction of FM service in housing sector. Facilities, 28(5/6), 306-320. doi: 10.1108/02632771011031538 